\title{
Law in Education: A Reminiscence with Some Footnotes to Robert Cover's Nomos and Narrative
}

\author{
Joseph Lukinsky†
}

Speak the truth to one another, render true and perfect justice in your gates.

-Zechariah 8:16

\section{INTRODUCTION}

Nomos! ${ }^{1}$ An incredible work! What is not in it? Legal history, legal theory, Biblical and Talmudic deliberation, literary criticism, anthropology, psychology, philosophy of science, . . . I could go on. It is more than any category into which it can be pigeonholed. I told Bob Cover when I first read it: "It's not the best article I've read about X or Y; it's the best article I've read about anything!"

Here, I respond to Nomos as an educator, with some broad general reflections on the role of law in education. These reflections embody some of the impact that the years of friendship with Bob have had upon me, an offering to the memory of Robert Cover, my extraordinary student, friend, colleague, and teacher. Zikhrono li-vrakhah!-may his memory be for a blessing.

First, a reminiscence. In the summer of 1960, I was assistant rabbi and youth-program director at Congregation Kehillath Israel, Brookline, Massachusetts. I hired Bob Cover, then sixteen years old, for the summer to help prepare educational programs and materials for the coming year. The summer's work, for which Bob received the magnificent sum of one hundred dollars, took place every afternoon, but the mornings were for study of the Talmud. From 11:00 to 12:00 we would review what he had studied on his own during the previous two hours. Often, I admit, the

$\dagger$ Professor of Education, Jewish Theological Seminary of America; Professor of Religion and Education, Teacher's College, Columbia University. I gratefully acknowledge the assistance of the Yale Law Journal editorial staff, especially the helpful suggestions of Ted Gentry and the "Talmudic" feedback of Steve Gold. Responsibility for any errors is mine.

1. Cover, The Supreme Court, 1982 Term-Foreword: Nomos and Narrative, 97 HARv. L. REv. 1 (1983). 
Talmudic discussion continued through lunch into the afternoon's "work" period.

I am reasonably certain after twenty-six years that we studied a portion of the Babylonian Talmud that deals with the laws of theft, conversion, and restitution. ${ }^{2}$ Much of this material was not in force by the time the Talmud was edited in the sixth century, yet it, and similar Talmudic sources, were and are the wellspring and expression of Jewish consciousness down to the present day.

Bob had some previous Talmudic background, having studied in the high school department of the Boston Hebrew College, but the text, with its Aramaic terminology and condensed and rigorous logic, was not easy. Nevertheless, before the summer was over I had the distinct impression that I was no longer the teacher but had become his haver (fellow student) ${ }^{3}$ in some respects, he had become the teacher!

It was during this period that we hatched a crazy idea that we called "The American Talmud." Our plan was to bring together outstanding authors and thinkers, along with stories from their lives and works. For starters, we identified Freud, Einstein, Marx, and Darwin (the irony of using these authors in our "American" Talmud was, I think, lost on us then)-people who significantly joined the great human issues. We would cluster them, with scissors and paste if necessary, in an interactive style bearing the hallmarks of Talmudic discourse and logic. That is, we did not plan to present these thinkers in the usual serial thematic anthology format (what each had to say about this or that topic), but rather in a constructed deliberation with one another. The essential idea was to present sources whose original formats were linear and univocal in a multiperspectival, dialogic, simultaneous debate on contemporary issues. We wanted to experience the deliberation, the inquiry itself, not the separate conclusions, as each of these greats hurled challenges at the others. We would not be bound by the need to use their actual words. We would supply the connective tissue for their hypothetical debates from what we already knew or could learn about their views.

Oh, I wish I had notes from those planning sessions: the arguments as we chose the sources, tried to understand them, and juxtaposed one against the other, our sense of the different directions in which the whole enterprise might go, and more. What sounded so good in the discussion

2. The ninth chapter of Massekhet (tractate) Baba Kamma, entitled Hagozel Etzim . . ("If a man stole wood and made it into utensils...."). Baba Kamma 93b.

3. Haver is the Hebrew term of which Cover is a transliteration. It means literally "friend," but is used in the rabbinic tradition as a term for one with whom one studies Talmud in a collegial relationship, i.e., b'havruta. In Talmudic times, title haver was conferred upon those who accepted a strict regimen of observance or, later, upon scholars of singular ability. It evolved over time to its present meaning. See Haver, 7 ENCYClopedia JudaiCa 1490-91 (1971). 
between us, alas, was more interesting than the modern Talmudic inquiries that we were able to construct on paper, perhaps itself a clue to a critical difference between oral and written traditions. I remember only "Rabbi" Freud slugging it out with "Rabbi" Marx and the difficulties of speculating beyond what we knew from the actual sources to what they "would have said" in different situations.

I do not remember why the project was aborted after a while. Mainly, I suppose, it halted because the summer came to an end and we had no more large blocks of time; also, we did not know the material well enough to work in it spontaneously and naturally. We were probably pulling abstractions out of context, relying on stereotyped expressions divorced from the great narrative worlds from which the chosen thinkers drew. ${ }^{4}$

Although the project was not completed, upon reflection I see that I have continued it in my own educational work. I will not presume that Bob Cover's great work was influenced by the modest experience that I have described, but it is one way that he touched my life. I will try to carry it forward a few steps farther, nurtured by my reading of his Nomos and Narrative.

\section{The Nature of Talmud}

The Talmud ${ }^{6}$ is, after the Hebrew Bible, the greatest work in importance for Jewish tradition. All contemporary Jewish institutions-synagogue, liturgy, holidays, etc.-as we know them are impossible to understand apart from the way that they are crystallized and developed in Talmudic literature. The Talmud also contains a vast corpus of civil and criminal law, in addition to legalistic treatment of questions more commonly associated with religious practices. It is a vast anthology of centuries of legal argument, religious speculation, scriptural exegesis, historical and quasi-historical sources, personal legends, specific facts, fantastic imaginings, and more. The editing is associative. One point leads to an-

4. Cover, supra note 1 , deals extensively with the relation between law and its narrative roots and expressions in different nomoi. There is interesting literature on "narrative modes of thought," see Bruner, Narrative and Paradigmatic Modes of Thought, in Learning and TEACHING THE Ways of KNowing 97 (1985) (84th Yearbook of the Nat'l Soc'y for the Study of Education, pt. 2) [hereinafter WAYs of KNOWING], and on the relationship of narrative and theology, see M. GoldBERG, Theology as Narrative (1981); see also T. Driver, Patterns of Grace (1977).

5. Cover's other fine works carry on the same ideas. I have, however, chosen to focus on Nomos.

6. See D. Halivni, Midrash, Mishnah, and Gemara (1986). I wish to thank Professor David Halivni for his responses to my questions about his research. My discussion of Talmudic deliberation and the redaction of the Gemara draws on Professor Halivni's oral communications as well as his book. He is, of course, not responsible for any errors on my part. For more on the Talmud, see Goldenberg, Talmud, in BACK To THE Sources 129 (B. Holtz ed. 1984); D. Daube, Collabora-

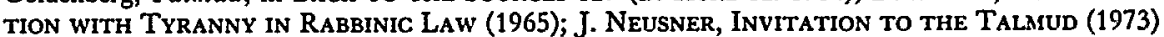
(adapted for young people as LEARN TALMUD); Holtz, Introduction: On Reading Jewish Texts, in BACK To the SourCeS 11 (B. Holtz ed. 1984); Holtz, Midrash, in id. at 177. 
other. A legal discussion leads to a story, a scriptural interpretation, a fanciful piece of imagery. The arrangement of the Talmud, unlike that of modern books, is not developmental, with the basics set forth first and the rest following as logically as possible. ${ }^{7}$

\section{A. A Tradition of Deliberation}

In about 200 C.E. ${ }^{8}$ the Mishnah, a roughly thematic collection of legal traditions, was produced. ${ }^{9}$ It was probably intended to be a definitive collection of authoritative traditions to be studied, not a compendium of binding or statutory law. ${ }^{10}$ However, even though the Mishnah contains some explicit Scriptural interpretation (Midrash), its legal statements are presented primarily in apodictic style, eliminating both the Scriptural derivation and the legal deliberations out of which they emerged. The Mishnah became the authoritative central study book of the rabbinical academies of Palestine and Babylonia, where the discussions of the Mishnah were later-in the late fifth and early sixth centuries C.E.-edited as the Gemara, with two versions corresponding to the two localities. ${ }^{11}$

The Gemara relates to the Mishnah as earlier sages related to the Bible. The scholars of the Gemara ${ }^{12}$ started from the assumption that they were searching for and determining the meaning of God's revelation to the Jewish people. ${ }^{13}$ To do this, they needed to reconcile the various earlier traditions that had been collected in the Mishnah, the Tosefta (a similar collection), and non-anthologized material handed down orally (Beraitot). Often, these scholars transmitted the original deliberation behind the Mishnaic "product," if it has been preserved. When necessary, they hypothetically reconstructed it in order to reconcile the various sources insofar as they understood them to be in conflict. ${ }^{14}$

7. D. HaLIVNI, supra note 6 , at 100 .

8. "C.E." denotes Common Era, a term used by Jews in place of "A.D."

9. Production was by means of oral publication, as demonstrated by S. Lieberman, The Publication of the Mishnah, in Hel.lenism in Jewish Palestine 83, 87 (2d ed. 1962).

10. The editor was Rabbi Judah Ha-Nasi ("The Prince"), who combined earlier collections into six Sedarim ("orders") composed of 63 Masekhtot (tractates or thematic subdivisions-singular Massekhet), covering the whole range of ancient Jewish law, expanded Biblical interpretations, and other areas.

11. Together, Mishnah and Gemara make up the Talmud, although sometimes the Gemara itself is called Talmud. In later times, the Babylonian Talmud (Talmud Babli) became more widespread and popularly studied than the Jerusalem (or Palestinian) version (Talmud Yerushalmi), because, among other reasons, the Diaspora academies of Babylonia achieved religious hegemony, and the Talmud Babli has a more fully developed and more elegant style than the Jerusalem Talmud.

12. These are the Amoraim, Stammaim, and Saboraim. See D. HALIVNI, supra note 6 at 98. Stammaim is a term created by Halivni to identify the sages who created the discursive, deliberative material of the Talmud, the anonymous connective tissue that characterizes the Talmudic form of argumentation. Id. at 76 passim.

13. See Goldenberg, supra note 6; J. NeUSNER, supra note 6; Holtz, Introduction, supra note 6.

14. See D. Halivni, supra note 6 , at 77,79 . 
The deliberations in the Gemara usually come to no conclusions with regard to what the law will be in practice. In the time of the Gemara, practice was probably diverse, with the rules of various local jurisdictions depending upon which scholars were recognized in a given place. ${ }^{18}$ The method of the Gemara is discursive, reflecting the dialectic among these scholars. Lines of discourse are followed up, often at length, even when they are peripheral to the main line of argument. ${ }^{18}$

The task of the Gemara, then, is to be a deliberative interpretation of the largely apodictic Mishnah, and to recapture the lost deliberation of the earlier period. When necessary, the Gemara even invents-reconstructs if you prefer-the original argument, or the very facts of the original case. To describe it this way makes it seem artificial, but when experienced by the student, Gemara is a rich and textured normative "world," something like what Gover was later to call a nomos. This is especially true during traditional oral study of the Gemara, when the students expressing the argument on the page tend to speak for and with the sages in their confrontations, as if the sages were talking to each other today, even though they may have lived centuries ago, and centuries apart from one another. ${ }^{17}$

In addition to the contemporaneity that the traditional and dialogical form of study brings about, the structure of the page itself adds a "McLuhanesque" factor. From the time of the Daniel Bomberg printed edition, ${ }^{18}$ the commentaries and references to later codes have been printed "around" the main Talmudic text, symbolically linking the commentaries to the text and to each other, as if their dialogue also takes place across the page. The printed page of Talmud reproduced below is exemplary. ${ }^{10}$

The Talmud assumes from the beginning and on every page thereafter that the reader already knows the rest. To study Talmud is, as it were, to recall what one already knows or is supposed to know; for a Jew, to

15. Only later, when the insecure political situation of the Jewish people required more uniform practice, did scholars develop uniform principles for determining the law.

16. Halivni notes:

The Stammaim [scholars of the Gemara who flourished between 427 and 501 or 520] were concerned almost exclusively with the "give and take," . . . . Page after page is filled with discursive material without any discernible trend to tell us what the final decision ought to be. To the Stammaim, theoretical learning was a main mode of worship, worth pursuing even if it does not lead to practical decision making.

D. HaLivni, supra note 6, at 76-77.

17. See M. AleXENBERg, Toward an Integral Structure Through Science and Art, in MAIN Gurrents in Modern Thought 149 (1974); S. Heilman, The People of the Book (1983). There are two dialogues, the dialogue on the page and the dialogue between the students who study b'hauruta-in pairs. B'havruta has the same root as haver. See supra note 3.

18. 1520-1523 C.E. The pagination of this first printed edition of the Talmud has been kept in all standard editions.

19. No two printed pages of the Talmud look exactly alike. The amount of Talmudic text printed on a given page depends on the amount of associated commentary, all of which is printed on the page with the text it annotates. The arrangement, "around" the main text, of the various commentaries depends on their sizes relative to one another. 


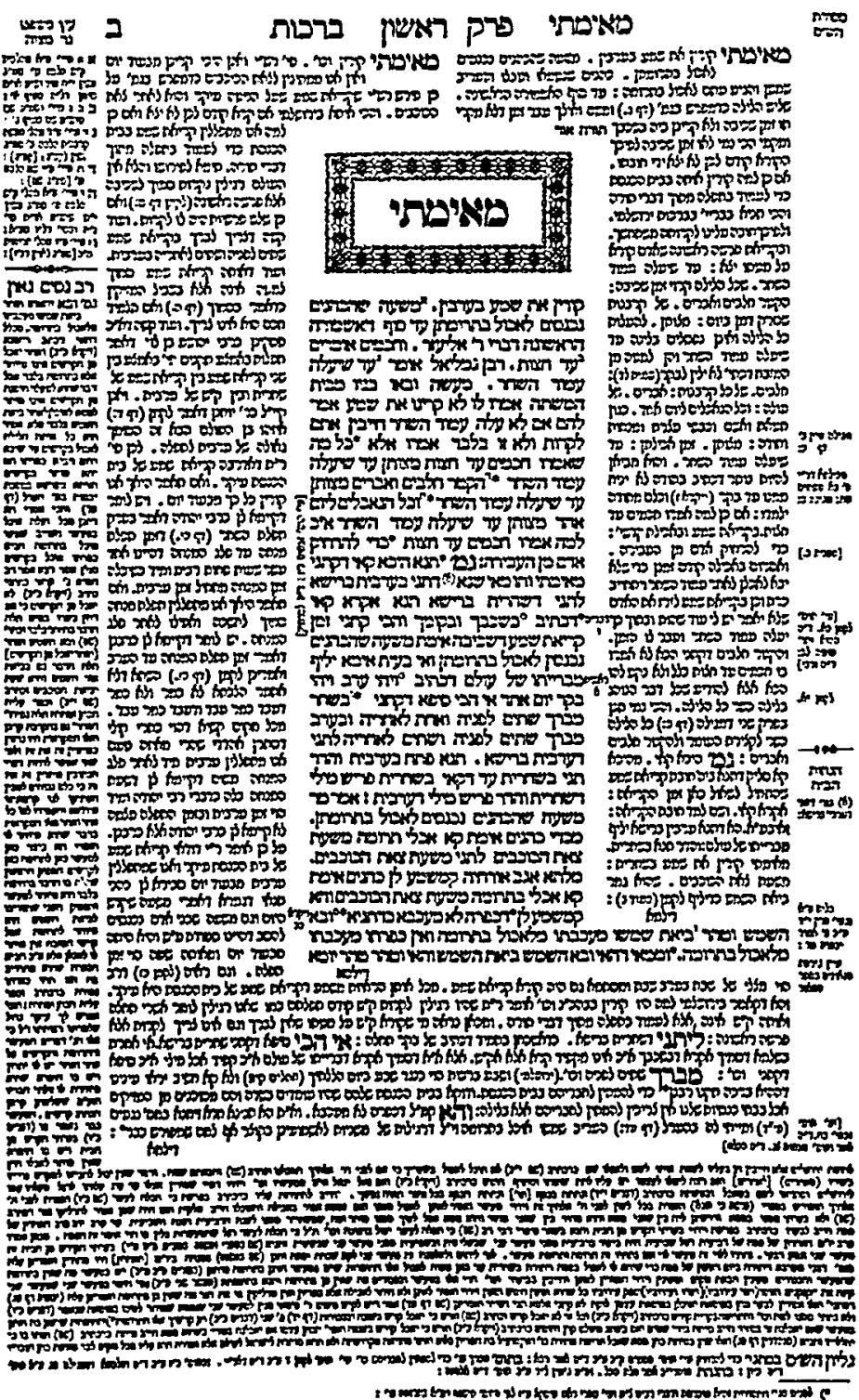

COURTESY OF THE LIBRARY OF THE JEWISH THEOLOGICAL SEMINARY OF AMERICA

First page of the Tractate Berakhot in standard edition of Talmud. 

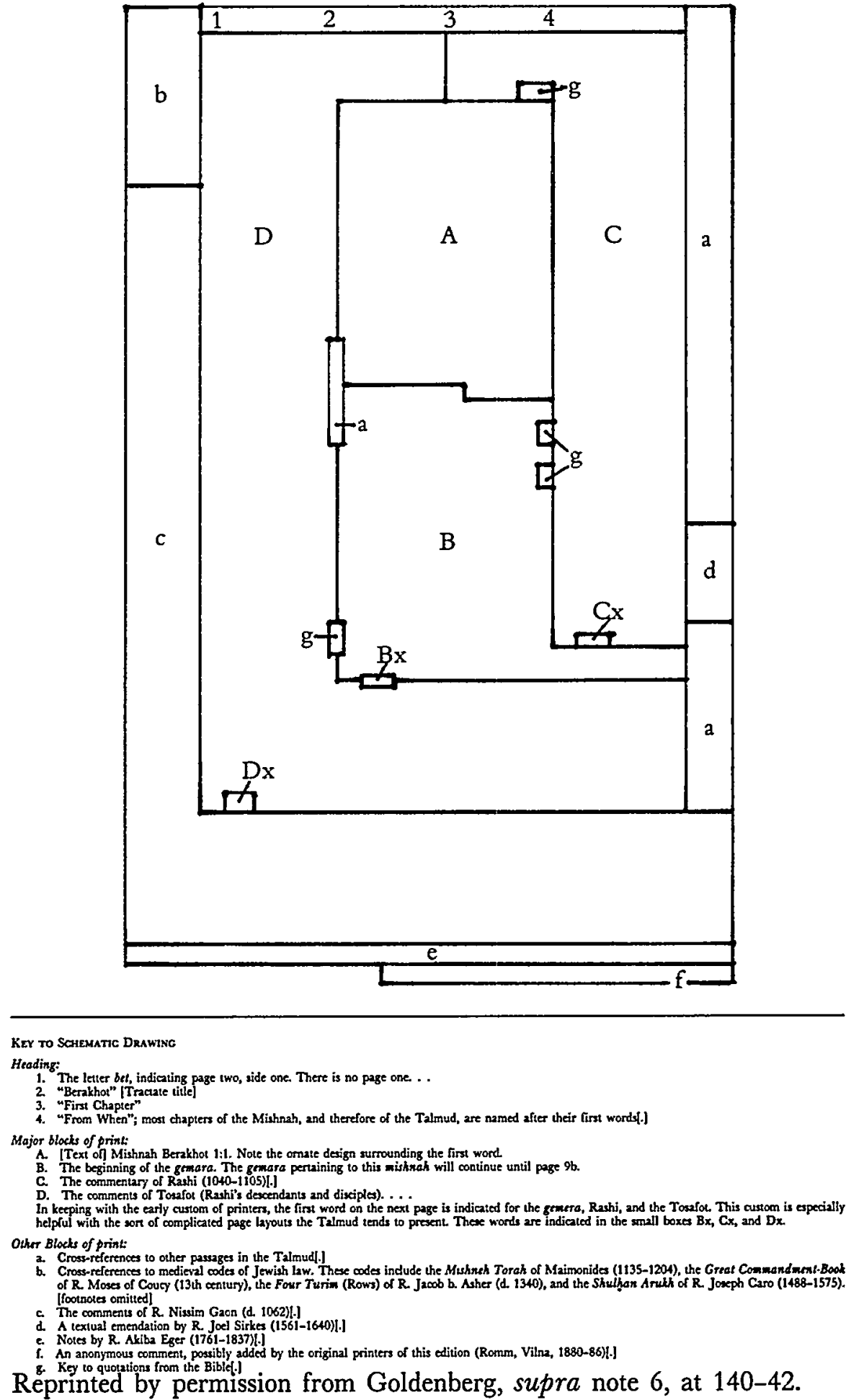
articulate that which has already formed his existing Jewish consciousness. ${ }^{20}$ The Jew who is alienated from this consciousness is thereby invited to simulate the socialization process which would have produced it, and even to find those residues that are indeed present, though not in the awareness. What does one do with a book that presumes the end in the beginning? The Talmud is called in Jewish tradition Yam Ha-Talmud ("the sea of the Talmud"). What does one do in the sea? One swims!

\section{B. Recapturing Deliberative Style}

Modern books are linear and present the perspective of the individual author. The author's inner deliberation with other perspectives is, for the most part, buried and implicit in the smoothed out, reasoned argument that is published or presented orally. If another view is presented at all, it is usually refuted or incorporated, not given a fair presentation. The other view never gets the opportunity to reply in medias res. On those occasions when another view is fully stated, the same problem arises: That perspective too appears in a polished and univocal guise. The reader or listener is left to his own devices to put the argument together. If each side is well constructed and convincing this task is often difficult. The framework and presuppositions of each author are hidden in the editing, and they may seem to be speaking past each other. ${ }^{21}$

Experienced scholars often conduct their inner deliberation intuitively and may even find it hard to make this operation explicit to themselves after the fact. The orderly thought process scholars describe after completing their work may bear little relation to their actual erratic course, charted by leaps of creativity. They may find it difficult to recall it to themselves, much less explain it to others. Such explanation is notoriously lacking in many scholarly papers and much teaching by scholars. The curriculum reform movement of the ' 60 's, which tried to build curriculum (the "new" Math, Physics, Social Studies, etc.) on the cornerstone of scholars' authentic knowledge and methodology, had to face this problem. ${ }^{22}$ The division of knowledge into "disciplines" enhances the difficulty. Disciplines are useful constructions of meaning that make it possible to handle the otherwise intractable complexities of life in the raw. Life itself is neither historical, sociological, psychological, nor biological. Even

20. Cf. M. Kadushin, Organic Thinking (1938); Norton, On Teaching What Students Already Know, 82 ScH. Rev. 45 (1973).

21. See the outstanding essay on participatory reading, Schwab, Enquiry and the Reading Process, 11 J. Gen. Educ. 72 (1958), reprinted in Science, Curriculum, and Liberal Education: Selected Essays 149 (I. Westbury \& N. Wilkof eds. 1978) [hereinafter Selected Essays].

22. See Lukinsky, Structure in Educational Theory (pts. 1 \& 2), 2 Educ. PhIL. \& TheOry 15 (1970), 3 id. 29 (1971); see also J. Bruner, The Process of Education (1960); Schwab, Education and the Structure of the Disciplines, in SELECTED ESSAYS, supra note 21, at 229-72. 
within disciplines, especially in the social sciences and the humanities, schools of thought with their separate frameworks give the student an illusorily fragmented yet smoothed out version of reality. ${ }^{23}$ The usefulness of the disciplinary structure of knowledge obscures the fact that, at some point, a synthesis is necessary; the lack of this synthesis is, for most people, the source of greatest disappointment concerning their education. This synthesis need not smooth out all differences, but rather must articulate the tensions that exist in a more total view; the experience should be one of participating in these tensions, of feeling the pushes and the pulls.

The goal sounds almost unattainable, especially for the non-scholar. Yet this is exactly what happens in the study of the Talmud. It became and remains a book that a relatively large number of non-professionals study, a scholarly work that almost can be considered a popular book for the masses. It is studied by scholars and non-scholars alike, and even by scholars and non-scholars together. ${ }^{24}$ There is something enormously compelling about the style, the participation in the inquiry itself, the empathic involvement in the deliberative decisionmaking process, and the reenactment of the dramatic process of the construction of meaning. The model of Talmudic inquiry is, I contend, worth pursuing further as a neglected paradigm for the improvement of the social studies curriculum. The model also can be used to enhance the role of law in education outside the professional study that takes place in law schools, and perhaps even there.

\section{Teaching the Constitutional Tradition as Talmud?}

The ultimate fantasy for the American educator has to be that the American constitutional tradition could reach a state in which it is studied by average Americans, not only in school as part of a required Civics course or American History unit, but for recreation because it is captivating and fun, a hobby to be pursued in one's spare time! In this year of the Constitution's bicentennial, much effort has gone into increasing awareness of the Constitution and its tradition at both scholarly and popular levels. Major efforts are underway from elementary school to the university. Scholarly conferences abound. ${ }^{25}$ Let me join the fantasy here and suggest what it would take to present the constitutional tradition Talmudically.

\footnotetext{
23. See Schwab, supra note 22 .
}

24. S. Heilman, supra note 17. Heilman makes a strong case for the social affirmation of communal identity and commitment aspects of such study in laymen's groups.

25. For one attractive and important resource, see the periodical This ConstiruTron: A BiCENTennial. Chronicle, Sept. 1, 1983 (first issue), and quarterly issues beginning with Spring, 1984. 


\section{A. Applying the Talmudic Model to the Founding Fathers}

The cardinal sin of history teaching is the assumption that what happened had to happen that way, and that the task of teaching is to explain why. The ideas of the "losers" in history are often dismissed and the ideas of the "winners" lose their sharpness when they are viewed in only one dimension. The problem is not that the opposition is not mentioned, but that students are handed a finished product, a "rhetoric of conclusions," which deprives them of the potential experience of understanding those ideas in depth.

The dynamic deliberations in Philadelphia in the summer of 1787 that produced our great national document are preserved in the official minutes of the Convention and in the notes of James Madison and others. ${ }^{27}$ The views of the Federalists who promoted ratification are presented in the well-known Federalist Papers, but the views of the Anti-Federalists, without which the Federalist views are not completely understandable, also need study. ${ }^{28}$ In this sense both the Federalists and the AntiFederalists are Founding Fathers. The nomos was shared; it was a matter of emphasis. As Storing points out, ${ }^{29}$ the most compelling argument of the Federalists was that they proposed to change the situation, whereas the Anti-Federalists sought only to maintain the status quo. The latter's substantive arguments, however, were no less in quality and wit. I am convinced that the Talmudic model has something to contribute here.

Deconstructionist literary criticism, which has become increasingly relevant to some schools of legal theory, ${ }^{30}$ restates the point.

[Jacques] Derrida contends that the structures-linguistic and otherwise-that pattern human behavior result from acts of exclusion and repression. As a post-Freudian, he realizes that the excluded does not disappear but remains to disrupt the structures constructed to domesticate it. The repressed returns to destabilize every structural totality-social, political, religious, psychological or literary. In deconstructive criticism one attempts to open a gap in every work by teasing out the repressed that the text struggles not to express. In contrast to the structuralist, who continues the philosophical project

26. See Schwab, The Teaching of Science as Enquiry, in The TeAching of ScIEnce 3 (1962).

27. All are collected in Max Farrand's classic, The Records of THE Federal Convention of 1787 (M. Farrand rev. ed. 1937); see also D. Halivni, supra note 6. Halivni points out the similarity of Farrand's efforts to "sift through different versions of the deliberations" of the Convention to those of the modern critical Talmud scholar who seeks to reconstruct the original Talmudic deliberation. Id. at 138 n. 10.

28. For a discussion of Anti-Federalist views, see H. Storing, What the ANTi-Federalists Were For (1981) (also available in 1 The CoMPlete ANTI-Federalist 3 (H. Storing ed. 1985)).

29. See id. at 7-14; see also M. Kammen, The Origins of THE Constitution xvi (Penguin 1986).

30. See Balkin, Deconstructive Practice and Legal Theory, 96 YAL.E L.J. 743 (1987). 
by translating the irrational into reasonable language, the deconstructive critic insists that something always escapes language. There is a remainder that is not only unsaid but unsayable. ${ }^{31}$

Judicial opinions are historical crystallizations of ongoing disputes that have persisted throughout our history. The majority and minority decisions of the Supreme Court freeze the ongoing dialectic, as it were, around certain focal points, but the process continues even then, as one sees in the rise of minority opinions to later prominence. ${ }^{32}$

It is this continuation of the dialectic that I suggest be captured. The Talmudic dialectic, in Halivni's view, is often an artificial reconstruction after the fact. It is, however, experienced by the student as if it were taking place now. The minority and majority decisions of the Supreme Court are written after the conference of the Justices is over and they retire to their respective chambers to reflect and formulate their opinions. What if we had a tape recording of their interactive discussions around the table and could join them there? What if the Justices of one court could interact with those of other times, Brandeis and Rehnquist, Earl Warren and Warren Earl Burger? To construct such deliberations retrospectively on the basis of the published majority and minority decisions would be to parallel the redactional process of the Talmudic editors.

I am suggesting not only that the history teacher recapture the "What ifs" of history-the knowledge that "things did not have to happen the way that they did, [that] with some different twists of fate, Americans might today live under a much different system of government. ${ }^{333} \mathrm{I}$ am rather suggesting that we recapture the "feel" of the deliberations themselves. Americans are not well informed about the nature of legal deliberation, and are willing enough to consider the "process of legal thinking" a matter for experts. The conclusions of historical legal deliberations are not presented in an interesting enough manner to attract the attention of most people. Thus, the idea that the study of law for its own sake could be a popular, lifelong, and intensely pleasurable activity, probably seems as

31. Taylor, Descartes, Nietzsche, and the Search for the Unsayable, N.Y. TIMEs Book REv., Feb. 1, 1987, at 34.

32. See A. BARth, Prophets with Honor (1974). Barth discusses "prophetic" dissents which enunciated arguments that later became accepted legal principles. Two notable examples are Justice John Marshall Harlan's dissent in Plessy v. Ferguson, 163 U.S. 537 (1896), which prefigured Brown v. Board of Education, 347 U.S. 483 (1954), and Justice Hugo Black's dissent in Betts v. Brady, 316 U.S. 455 (1942), foreshadowing his majority opinion overruling Betts in Gideon v. Wainwright, 372 U.S. 335 (1963). See also Cover, The Left, the Right and the First Amendment, 1918-1928, 40 MD. L. REv. 349 (1981) (discussing concurring and dissenting opinions in free speech cases).

33. Martin, Beyond Fireworks: New York's Cerebral Salute to 1787, N.Y. Times, Feb. 10, 1987, at B19, col. 4 . 
far-fetched as can be. Yet, the Talmudic model of students who study for the joy of the deliberation, and not to memorize conclusions, is instructive.

The constitutional materials we now study are presented in linear fashion. If indeed "the medium is the message," then we need to create a new medium, bringing together the warp and the woof. I visualize a format in which the text of the Constitution is unpacked and opened up, not merely accompanied by a linear commentary. The interspersing of reconstructed dialogues representing the Convention disputes and the Federalist/AntiFederalist debates, folklore elements, historical events and legends, later judicial opinions, and trial court cases would be rich and textured. It would create nomos.

An example here might help. Modern teachers present the debate at the Convention which led to the "Connecticut Compromise" as a power struggle between the large and small states that was finally resolved ingeniously by a compromise that only diehards who would rather the whole enterprise fail than give in could oppose. The issue, however, was more complex. As many point out, the constitutional process at the Convention, and in the later ratification events, hung in the balance on this point. ${ }^{34}$ It is only after the fact that the Compromise seems like the obvious and logical solution. It is difficult to cast ourselves back into the amorphous pre-Compromise situation, where the possibilities, options, and pressures were not so clear. The fears of the small states were real enough. Having just fought a Revolution to preserve local control over their lives, they were not so ready to relinquish control to a faraway entity.

The statement of Patrick Henry, incredible to a modern audience that takes for granted that "We the People" are indeed one people, is germane here. Henry was not a Convention participant, but it casts a new light on the Convention for us to transport him there, for he responded to the first words of the Preamble as follows:

[W] hat right had they to say, We, the People? My political curiosity, exclusive of my anxious solicitude for the public welfare, leads me to ask, who authorized them to speak the language of, We, the People, instead of We, the States? States are the characteristics, and the soul of a confederation. If the States be not the agents of this compact, it must be one great consolidated National Government to the people of all the States. ${ }^{38}$

Henry's objection, of course, was right on target. Consider this statement

34. E.g., Roche, The Founding Fathers: A Reform Caucus in Action, 55 AM. Pol. Scr. Rev. 799 (1961).

35. H. StORING, supra note 28, at 12 (quoting Patrick Henry, speech to the Virginia State Ratifying Convention, June, 1788). 
by Alexander Hamilton: "The clearest minds among the Federalists agreed that states are the soul of a confederacy. That is what is wrong with confederacies: 'The fundamental principle of the old Confederation is defective; we must totally eradicate and discard this principle before we can expect an efficient government." "36

The construction of a curriculum for the teaching of this issue would plunge the student back into the common nomos shared by Federalist and Anti-Federalist alike. It would seek to recreate the point at which the two sides divided on this issue, not merely to present the two sides in an orderly, precisely reasoned, linear fashion. It would follow the issue dialectically down through the Civil War to the Reagan Presidency.

\section{B. The Law and the Curriculum}

In this Section I will focus very broadly upon law-related aspects of school social studies curricula and connect the relevant points of this discussion to some questions regarding the teaching of law in law schools.

In recent decades, educators from the kindergarten to the university lecture hall have increasingly striven to integrate the study of law and the legal system with social studies and citizenship education curricula, as well as with other standard subjects such as history. In some cases there has been an attempt to introduce law into the curriculum as a field of study in its own right. ${ }^{37}$

By and large, such curriculum designs stress "learning about" law, about rights, duties, institutions of the law and their histories, legal "know-how," law and society, and the like. Freund found these approaches lacking; they did not, in his view, provide what he calls "a vicarious participation in the process of legal thinking through immersion in some of the problems and the literature of the common law."s8 Freund's proposal for the curriculum was to do just that, to teach the law in the schools as "an enterprise, an ongoing process, whose study contributes to an enlarged understanding of and participation in, the world around us." 39

36. Id. (quoting Alexander Hamilton, quoted in The Debates of the State Conventions on the Adoption of the Federal. Constitution, as Recommended by the General Convention at Philadelphia 234 (J. Elliot 2d ed. Philadelphia 1866)).

37. For a fairly recent survey of efforts to introduce law into the school curriculum, see M. NELSON, LAw In THE CURRICULUM (1978); see also Freund, The Law and the Schools, 36 HARv. Educ. REv. 470 (1966) (important theoretical proposals), reprinted in P. FREUND, ON LAW AND Justice 108 (1968); A. Elson, Educating School Children in the Law (1967) (Ford Foundation Report with appendix listing many curriculum projects); W. GiBson, Lessons IN Confuct (2d ed. 1972) (Boston University Law School Project, including curriculum units on broad range of standard legal subject areas). The last two sources are typical material of this type.

38. Freund, supra note 37, at 471.

39. Id. at 470 . 
Over the past two decades, a spate of new approaches to the social studies in general, ${ }^{40}$ have purported to involve students in various sorts of simulations, case studies, and practical deliberations in order to teach skills such as "critical thinking," problem-solving, and decisonmaking. There have been many approaches; some of the main trends have been spinoffs of the cognitive moral education theories and programs of Lawrence Kohlberg ${ }^{41}$ or the Values Clarification Movement originated by Louis Raths and colleagues. ${ }^{42}$ The skills sought are practical and deliberative and are intended to serve students as tools for more successful involvement with the problems of everyday life and with the issues faced by citizens in a democracy. Most of these curricula stress the students' clarification of personal values when confronted with a situation. The presentation, however, tends to focus upon predetermined alternatives; students receive little opportunity to generate their own set of alternatives from study of the raw situation. Nor are students given guidance as to how to entertain the various options. Discussion of cases after the decision has been made is meant to describe and justify the outcome after the fact. ${ }^{43}$

Cohen's study of curricula for teaching the different forms of practical deliberation calls in question-indeed, in my opinion convincingly refutes-the exaggerated claims of these curricula. ${ }^{44}$ Cohen compares Schwab's theoretical model ${ }^{45}$ of practical deliberation with written accounts that preserve what really happens when people deliberate in a practical context where a decision has to be made. ${ }^{48}$ Genuinely accurate accounts are hard to find; most published recapitulations of such delibera-

40. These approaches have been tried even in curricula that do not focus on the law as such. The best of the genre, I think, remains the Harvard Social Studies Project, directed by Donald W. Oliver and Fred M. Newmann. The most relevant material from this project is the booklet (and accompanying teacher's guide) Harvard Social. Studies Project, The Lawsuit: Legal Reasoning and Givil Procedure (1968), which is directed at junior high and high school students. The theoretical basis for the Harvard Project is presented in D. Oliver \& J. Shaver, Teaching Public Issues in THE High SCHOOL (1966).

41. See generally Moral Development, Moral Education, and Kohlberg (B. Munsey ed. 1980).

42. The basic text of the Values Clarification Movement is L. Raths, M. HaRmin \& S. Simon, Values and Teaching (1966); see also S. Simon, L. Howe \& H. Kirschenbaum, Values ClarIFICATION (1972).

43. See J. Schwab, College Curriculum and Student Protest 113-82 (1969) (criticizing this common style of teaching about law).

44. See B. Cohen, Criteria for Developing Curricular Proposals for the Teaching of Deliberation (1974) (unpublished doctoral dissertation, Univ. of Chicago); see also Cohen, The Teaching of Deliberation in the Jewish School, in 2 STUDIES IN JEWISH EDUCATION 122 (M. Rosenak ed, 1984) [hereinafter Teaching Deliberation].

45. J. SchwaB, supra note 43, at 148-73.

46. Cohen finds rich material in accounts of the ascent of Mt. Everest by Sir John Hunt, documents from the "Pentagon Papers," accounts of President Kennedy's handling of the Cuban missile crisis, and the records relating to Eisenhower's decision to proceed with D-Day in World War II. See B. Cohen, supra note 44. 
tions are "cleaned up" and focused, after the fact, to such an extent that they present a distorted picture.

For our purposes, the main points of Cohen's research are as follows: (1) These curricula force efforts at problem solving and critical thinking into models of theoretical inquiry that stress information gathering and hypothesis formation and testing. Dewey's model of thinking ${ }^{47}$ is artificially turned into a recipe for a step-by-step linear process. (2) "Relevant" factors are highlighted prematurely, in contrast to real situations. (3) The curricula ignore broader, "generic" considerations that will legitimate a choice of alternatives. Only the specific, focused data of the situation being examined are considered. (4) The mix of subjective and objective elements that one encounters in real settings is largely overlooked. (5) Most curricula assume that the process is linear, that the "steps" can be taught as discrete skills apart from a specific situation, and that all the steps are necessarily present in each case. ${ }^{48}$ There is more, but this work explains the disappointment that most educators have felt with their efforts in this regard. My impression is that despite increasing curricular sophistication and complexity, the basic thrust of Cohen's work is still valid. ${ }^{48}$ Students participate in the enterprise of practical deliberation in only the most superficial way.

\section{G. Educational Lessons for Law Schools}

Cohen studied, and criticized, social studies curricula that claim to teach modes of problem solving, critical thinking, and decisionmaking. Of course, the teaching of precisely these skills is stressed by law schools as their main raison d'être. Thus, I find it especially interesting that Cohen's critique of social studies curricula that claim to teach modes of problem solving, critical thinking, and decisionmaking resonates with critiques of legal education in law schools. ${ }^{50}$

In brief, since Langdell's creation of the case method in the nineteenth century, that method has dominated the teaching of law in law schools. For Levi, "[i]t is the greatest invention that has occurred in legal educa-

47. J. Dewey, How We ThiNk (2d ed. 1933).

48. See Teaching Deliberation, supra note 44.

49. Cf. Steinberg \& Caruso, Practical Modes of Knowing, in Ways of Knowing, supra note 4, at 133.

50. For my discussion of legal education in law schools, I have relied mainly upon material in $E$. Levi, Four Talks on Legat. Education (1952) (old but still good), as well as F. Dutile, Legal Education and Lawyer Competency (1981); H. Packer \& T. Ehrlich, New Directions in Legal Education (1972); see also ABA Section of Legal Education and Admissions to THE Bar, Report and Recommendations of the Task Force on Lawyer Competence (1979) (commonly referred to as the Cramton Report). 
tion. It provides a means whereby students can be made to participate in, and thus learn the art of legal reasoning."

The Socratic approach used by teachers in teaching by the case method challenges the student to compare precedents with the rules of law previously derived from them and to apply the reasoning to new cases. This is the characteristic teaching method of the first year of the law school curriculum, generally conceded to be the most interesting and important of the standard three year program. ${ }^{52}$

As Levi and others have noted, the student learning by the case method would indeed seem to be involved in the inquiry itself, in legal deliberation as it is conducted from the inside. In many important respects, therefore, the classic case method could serve as a model for teaching legal deliberation at other school levels. Facts are important, especially those that make the application of rules difficult, and law school professors are never happier than when they find a conflict of rules. ${ }^{53}$ But despite all its virtues there remains a flaw. The case method gets its facts mainly from appellate court case books. The original facts of the case as brought before the trial court are largely unavailable or unused. "It is to the credit of the law schools that they emphasize both fact and theory; it is too bad that frequently they do not know what the facts are."

In the classroom, the law student does not come in contact with the "situation in the raw." This unreality is made up for, in the legal realist approach, by stressing the importance of additional knowledge drawn from the social and behavioral sciences and from economics. It was also an impetus to the establishment of legal clinics where students get the opportunity to handle real cases, supervised by trained staff and faculty members. It is noteworthy that many approaches to social studies and civic education at the school level have also stressed the involvement of students

51. E. Levi, supra note 50 , at 17.

52. See H. PACKER \& T. EHRLICH, supra note 50, at 30-31.

53. For examples of almost gleeful descriptions of rules in apparent conflict, see D. LouisELL, G. Hazard \& C. Tatt, Cases \& Materials on Pleading and Procedure State and Federal 494-544 (demonstrating existence of difficult-to-reconcile case law on Erie problem); $i d$. at 903-44 (similar demonstration regarding scope of right to jury trial).

54. E. LEVI, supra note 50, at 31; see also Cramton, The Current State of the Law Curriculum, 32 J. LeGal Educ. 321, 331 (1982) (intermediate level of abstraction typical of appellate cases does not permit teaching of legal theory or of practical legal skills); Feldman \& Feinman, Book Review, 82 MICH. L. REv. 914, 928-30 (1984) (teaching of doctrine does not permit students to analyze facts in a context or to learn to make choices in presence of uncertainty); Shreve, Bringing the Educational Reforms of the Cramton Report into the Case Method Classroom-Two Models, 59 WASH. U.L.Q. 793, 796 (1981) (absence of facts from appellate opinions restricts students' exposure to true texture of cases).

For a description of a casebook which attempts to remedy the failings outlined above, see Martineau, Book Review, 57 N.Y.U. L. Rev. 346, 351-54 (1984) (reviewing S. MeNrschikoff \& I. Stotzky, The Theory and Craft of American Law (1981)). Mentschikoff and Stotzky's text employs exclusively unedited cases, in order to provide students with available facts. Additionally, the authors include official summaries of the arguments of counsel. 
in real life situations. ${ }^{\mathrm{sb}}$ Yet clinical programs may suffer from the converse problem of not being well integrated into the broader curriculum. To function properly, a clinical program needs reflective guidance, connection to the rest of the curriculum, and sufficient exposure to the classic challenges of the law, which just may not "come up" in the clinical setting. ${ }^{.8}$

In sum, both in law school and in social studies or civic education programs that attempt to embody legal thinking, the assimilation of the process of legal thinking is contingent upon more than either the case method or practical experience alone can offer ${ }^{87}$ The case method may teach the rules of evidence, for example, but it may not teach the student how to approach the facts of a real case. The clinical activity may have great practical value, but it is limited by the quality of guidance that the student receives. ${ }^{58}$ There is often little coordination between the classroom and the field activities.

The Talmudic model offers a way between these difficulties. The point is not that the Talmud gets back to the facts of cases more adequately or even that the study of the Talmud is intrinsically more interesting. It is that to enter the study of Talmud is to enter the Jewish nomos in a participatory way, to engage in an inquiry that is taking place now. To be involved in the labyrinth of the discussion, of even rejected views, is to reexperience it in a very personal way, from inside the inquiry itself. This derives, as I have suggested, from the format of the text, its substantive style, and from the way it is studied. From any objective point of view, it may be a deliberation from the past, but these factors facilitate the student's making it his own.

By contrast, the law or civics student-whether studying decided cases,

55. See J. Lukinsky, Teaching Responsibility: A Case Study in Curriculum Development (1968) (unpublished doctoral dissertation, Harvard Univ.). Robert Cover was a central staff person in the summer camp Jewish citizenship program described in this dissertation.

56. This is a major issue of clinical training in all fields, including medicine, education, and the like, see J. Lukinsky, supra note 55; for example, this is the reason medical students seek internships in hospitals where the cases will be diverse. For further discussion of practical deliberation in medicine, see A. Elstein, L. Shulman \& S. Sprafka, Medical Problem Solving (1978).

For the continuing debate regarding the proper place of clinical training in a law school curriculum, see Anderson \& Catz, Towards a Comprehensive Approach to Clinical Education: A Response to the New Reality, 59 WASH. U.L.Q. 727 (1981) (presenting model of clinical education); Brest, A First-Year Course in the "Lawyering Process", 32 J. LEGal Educ. 344 (1982) (describing experimental course at Stanford Law School, employing simulated clinical exercises); Gee and Jackson, Bridging the Gap: Legal Education and Lawyer Competency, 1977 B.Y.U. L. REv. 695 (extensive study of history of legal education in America); Grossman, Clinical Legal Education: History and Diagnosis, 26 J. LEGAL. EDuc. 162 (1974) (assessment of clinical education as of 1972).

57. The focus in law schools may differ from that in law programs in schools. The latter may lay greater explicit stress on teaching legal thinking in a way that generalizes to skillful problem-solving and decisionmaking in the world at large.

58. Cf. H. PACKER \& T. EHRLICH, supra note 50, at 42-43 (pressures of clinical situation can inhibit good skills training). 
conducting simulations, or even facing clinical situations-is subjected to narrow over-focusing of the problem even as he or she is led through the decisionmaking process. Because I am not a legal scholar, I cannot claim the kind of understanding that would allow me to construct a complete legal curriculum in Talmudic style. It seems to me, however, that materials from the general legal tradition lend themselves to being studied this way. It may not be the most practical way of training lawyers, in the short run, but it might hold the most interest for non-lawyers. And it could ultimately be engrossing as a humanistic activity, but one with a deeper practical worth, for lawyers in training too.

The United States Code Annotated, for example, is somewhat akin to the Mishnah. It preserves the currently valid interpretations of Federal statutes derived from Federal court opinions. These interpretations are presented in apodictic fashion with some brief relevant detail from the case, sometimes more, sometimes less. Overruled interpretations and cases no longer relevant appear only in earlier volumes. The deliberation is gone. It is static, implicit. It needs to be reconstructed by the reader who flips back and forth between the statute and the case to see how one relates to the other. To find the background, the reasoning in the case supporting the interpretation, one looks up the case in a reporter that presents the case in greater detail, but at the stage of the final argument of the court. That is, the reasons for the decision are given in detail only after all the reasoning has been done, with the weighting on the side of the conclusions already reached. It seems to me that some solid curriculum work could turn the Annotated Code, and similar sources, back to an earlier stage, and create "Talmud."

Another example: A casebook like Prosser's Cases and Materials on Torts, ${ }^{60}$ which is one of the staples of the first year of law school, presents civil cases in detail and seems highly amenable to what I am suggesting. It is already on the borderline. The notes after each case, which usually simply refer to other cases, could, if followed up, supply the cutting edge that I am looking for and reopen the dialectic. Good Socratic teaching, the

59. Interestingly, one of the earliest American legal works, St. George Tucker's edition of Blackstone's Commentaries, has some intriguing Talmudic characteristics. W. BLACKSTONE, CoMmentARIES (St. George Tucker ed. Philadelphia 1803). In many places, Tucker presents on the same page Blackstone's original text, selected notes written by Edward Christian for his English edition of the Commentaries, and Tucker's own notes on Virginia law. See, e.g., 2 id. at 281 (waste), 378 (wills), 448 (contracts for sale). Although there is no dialogue in Tucker's work, the reader is strongly invited by the chronological development and the sounding of different voices to create for himself a story about the process by which legal rules evolve. At its best, Tucker's Commentaries provides the reader an entrée into legal discourse.

It is a nice coincidence that one of Bob Cover's earliest published works was a review of the 1969 reissue of Tucker's edition of Blackstone. Cover, Book Review, 70 Colum. L. REv. 1475 (1970).

60. W. Prosser, J. Wade \& V. Schwartz, Cases and Materials on Torts (7th ed. 1982). 
high point of the case method, apparently also achieves this, especially when the notes are dealt with in class. Never having experienced it, I assume it is highly involving. It is, though oral for the most part, a textured inquiry with possibilities. Good teaching is necessary to make it come alive, however. This is so even for law students, who tend, I am told, to be concerned more with the practical conclusion, the rule of law that they can use, than with the thrill of the chase. What I seek is the simulation of the live discussion constructed on the page. I want students, without a Socratic teacher, to be able to continue, stimulated by the page, "Socratically" on their own.

\section{A GurRiculum for EXPERIENCING the NOMOS: A Prerequisite to the Construction of Meaning}

Life is filled with amorphous situations, complex interrelations, puzzles, and perplexities. The human task is to construct meaning. ${ }^{61}$ Education is supposed to help with this task.

Scholars by definition construct meaning in the realms of their scholarship, but this meaning often functions analogously to what Cover calls the "jurispathic" function of the law. ${ }^{62}$ We are subject to their hermeneutic, their understanding. We are not helped to move through the scholarly problem as they first faced it. Instead, we learn only to understand the solution they reached, after the earlier stages, where meaning was truly constructed, have been filtered out. ${ }^{63}$ We come to the drama, in most cases, too late, after the first two acts of the play are over.

The task is not to confront the choices of the scholar-neither those already made nor those that need to be made-at least not at first. The first objective is to reopen the possibilities, to return to the fluid situation of "jurisgenesis," where the choices are real, but yet to be determined. It is to feel the pulls of realities that are not yet ours.

To enter another realm, another perspective, an unvoiced reality that hovers over the explicit, to understand that alongside the Abraham who says "Here I am" is the Abraham who says "No," synthesis that is the sum of all articulations and goes beyond them. Cover

61. For a grand picture of how deeply rooted this human need is, see the story entitled $A$ Matter of Identity, in O. Sacks, The Man Who Mistook His Wife for a Hat and OTHer Clinical TAles 108 (1985).

62. See Cover, supra note 1, at 40-44.

63. H. PACKER \& T. EHRLICH, supra note 50, at 30 (teacher controls limits of discussion in case method); Schwab, supra note 21, at 149-63 (construction of meaning as participatory process).

64. See Cover, supra note 1, at 11-19.

65. Genesis 22:1. I am grateful to my colleague, Professor Samuel Laeuchli of Temple University, for this concept in the interpretation of the story of the Binding of Isaac in Genesis, part of his broader work in the re-experiencing of the classic myths. See also S. SPIEgel, The LaST TrIal. (J. Golden trans. 1967). 
powerfully evokes this synthesis in his treatment of the conflict between the Biblical law of succession of the first-born son and Biblical narratives of succession, which consistently ignore or oppose that law: "To be an inhabitant of the biblical normative world is to understand, first, that the rule of succession can be overturned; second, that it takes a conviction of divine destiny to overturn it; and third, that divine destiny is likely to manifest itself precisely in overturning this specific rule."66

Education needs to create worlds for students to experience, rather than to reduce such worlds to the learning of abstract concepts or information. Sports and games provide for a rich yet simplified experience of nomos that can fulfill educational purpose. ${ }^{67}$ Generally speaking, educators neglect the possibilities of this resource. ${ }^{68}$ They go far afield to look for examples, when one that is of great interest to people of all ages is so near at hand. Berger ${ }^{69}$ points to the world of play as an opportunity for understanding the meaning of transcendence. Authors like Roger Angell ${ }^{70}$ have noted that baseball particularly, not being bound to a clock, represents a timeless world that embodies the experience of the transcendent and, in light of its rich and relatively well known history, the transpersonal too.

As an example, I suggest the famous "pine-tar" game between the Kansas City Royals and the New York Yankees in $1983 .{ }^{71}$ In that game, Royals' third baseman George Brett's potentially game-winning home run was nullified because of the excess of pine-tar (used for secure grip) on his bat. In response to the protests of Yankee manager Billy Martin, who was waiting to invoke the "technicality" in just such an emergency, the umpires agreed that the amount of pine-tar on the bat violated the rules.

The incident led to a tremendous popular debate about the spirit and letter of the law. The arguments constituted perhaps the most widespread popular legal debate in American history. The only recent rivals were Watergate and the Baby $\mathrm{M}$ case, in which people were involved more in the personal and political issues than in the finer legal points.

66. Cover, supra note 1 , at 22 .

67. Piaget's classic description of how children learn "rules" through the stages of their construction of the meaning of rules in the game of marbles is, insofar as it is a narrative case study, perhaps more educationally successful in communicating his theory of stages than the rest of his book; at least it is a powerful dimension of the theory. J. Piaget, The Moral Judgment of The Child 13-108 (First Free Press ed. 1985).

68. See Lukinsky, Sports and Jewish Education, in Studies IN Jewish Education in Honor of Louis Newman (A. Shapiro \& B. Cohen eds. 1984).

69. P. Berger, A RuMor of ANgels: MOdern SOCIETy ANd THE Rediscovery of the SuPERNATURAL 60 (1969).

70. See, e.g., R. Angell, Five Seasons (1972) and The Summer Game (1962).

71. I have done a great deal of background research on the pine-tar case for purposes of turning it into a school unit as described briefly here. For an interesting view of the case from a legal perspective, and for sources of relevant materials, see Finkelstein, In re Brett: The Sticky Problem of Statutory Construction, 52 FordhaM L. REv. 430 (1983). 
During the days after the pine-tar game, the partisans of both teams and both sides of the argument argued loudly and enthusiastically. An editor of The Sporting News told me that more mail was received on the pine-tar ruling than on any other issue in that publication's history. ${ }^{72}$ Journalists, poets, politicians, and others entered the debate. The New York Times editorial page, truly coming out of left field, applied the pinetar incident to the issue of United States covert operations in Nicaragua! ${ }^{73}$ Since Congress had "expressly forbidden a secret war to overthrow Nicaragua's leftist regime," President Reagan must obey. Abraham Lincoln, "whom you might call a home-run hitter" would have agreed. "Slugger Reagan may not like the fine-print, but who exempted him?" the editorial continued, applying the "rule is a rule" thinking of the umpires' pine-tar decision. A letter by President Nixon was quoted on the air by Yankee broadcaster Phil Rizzuto in support of Brett, which impressed me greatly until the possibility occurred to me that Nixon was sympathizing with Brett for getting caught! Ira Berkow ${ }^{74}$ in the Sports Pages of the Times made the issue of letter and spirit ${ }^{75}$ explicit and interviewed Talmudist David Halivni on it.

After four days, the American League President Lee MacPhail overruled the umpires' on-the-field call for the first time in his career. His written decision reads like a Supreme Court opinion: it considers the materials on both sides of the question, notes the umpires' neglect of the precedents, ${ }^{76}$ and candidly admits the difficulty of reconciling rules in different sections of the apodictic Baseball Rule Book, especially when the game situation requires an immediate decision and the reasoning behind the rules is not clear.

72. Telephone interview with $R$. Ray (summer 1983).

73. Yankees, Bats, and Nicaragua, N.Y. Times, July 26, 1983, at A20, col. 1 (editorial).

74. Berkow, The Eternal Pine-Tar Case, N.Y. Times, Aug. 9, 1983, at B9, col. 1.

75. Finkelstein, supra note 71 , at $438-39 \mathrm{n} .73$, discusses this issue and another famous incident involving "technical" enforcement of baseball's rules-the case of "Bonehead" Fred Merkle. In 1908, Merkle's failure to run to second base while the winning run scored cost the Giants the pennant.

I believe that the two cases are different; the beauty of this inquiry is at the very point where the two cases are contrasted. At what point does enforcement of the rule become completely separated from the rule's intention and spirit? At what point does focus on "spirit" lead to anarchy? To be in this cutting edge of the dialectic is educationally more important than the specific conclusions.

Berkow, supra note 74 , misses the point by making some dubious analogies to suggest that, in general, if the "spirit" of the rules were applied the game would truly be distorted. Finkelstein similarly argues that the charm of the game inheres in strategies for using the rules to advantage and stretching them as much as possible. They both miss the critical difference between Merkle's baserunning mistake and Brett's bat. In the pine-tar case, strict enforcement of the rule would have been based upon an incorrect-albeit resulting from unclear formulation of the rule in its various versions-interpretation of the intent of the rule itself. There was no such error in the Merkle case.

76. The same thing had happened to John Mayberry of the Royals (in a game against the California Angels), and to Thurman Munson of the Yankees (against the Royals), in 1975. Mayberry's two homers were not taken away; Munson's single was. See Finkelstein, supra note 71, at 438. Mayberry vs. Munson eerily recalls Marbury v. Madison! 
At the time, MacPhail's decision, which was to the umpires' call as more leisurely judicial review is to the decisions of cops on the beat, was a bombshell. After MacPhail's carefully worded response, however, it was hard to remember the previous amorphous state of the discussion and the liveliness that characterized it. Working with this case Talmudically would be to recapture that feeling, pre-MacPhail, when the arguments of both sides were live and engaged. The newspaper accounts, the columnists, the dialogue as a whole, could, with some effort, be presented Talmudically. It is not just an argument about rules. It is a microcosm of a nomos that so many Americans share.

A more current example involves a tension that still exists. ${ }^{77}$ The National Basketball Association (NBA) does not allow the zone defense. The purpose is to speed up the game, on the assumption that a faster game is more crowd pleasing. This speeding-up has, however, been largely accomplished by the 24-second shot clock. College basketball, on the other hand, allows the zone and only recently has installed a shot clock (allowing more time, 45 seconds) to speed up its games. Connoisseurs often prefer the college game, even without the shot clock, enjoying the finesse required to penetrate the zone, in contrast to the more free-wheeling pass and shoot professional game. Yet, NBA coaches try to devise clever defenses that approach the brink of being a "zone" without actually inducing the referees to call a violation. This introduces a great deal of creativity that would be lost if the zone were allowed outright. We could try to weigh the pros and cons and decide, but whatever our choice, something is lost. The quest is not for the "correct" rule. There may be a decision at some point and that would raise another interesting issue, but the main point for our purposes is that the tension itself is so exquisite, so rich in its possibilities for looking at all sides simultaneously even without coming to any conclusions.

I once participated with the great psychoanalyst Bruno Bettelheim in a seminar in Jerusalem which dealt with the question of nurturing the thought processes of disadvantaged children. One educator raised the issue of children who thought that the astronauts' trip to and from the moon was not the same distance. After rejecting group members' suggestions for confronting this issue, Bettelheim said he would conduct an extended discussion, hearing out all the students' views at length. He noted that one of the problems of these children is that they are always told the answer and never have the almost tangible experience of thinking something through thoroughly. Bright chidren answer too quickly, limiting the experience of

77. For full treatment of this issue, see Koppett, Should NBA Legalize the Zone?, N.Y. Times, Apr. 4, 1978, at 38, col. 1. I have also in seminars related this experientially to Jewish law. See Maimonides Code, Mishneh Torah, Hilkhot Mamrim, Ch. 2. 
the thinking process for children who grasp the point more slowly and thus are simply given the "correct" result. After a long discussion, a teacher asked, "But what would you do to convince them of the right answer?'78 I will never forget Bettelheim's look of disdain! For him, the conclusion was not of primary importance if the discussion helped teach the children to think.

\section{Conclusion}

Education should give us generic memories of the human race that supplement, enrich, and, most of all, inform those which belong to each of us alone. To do this it needs to recreate those crucial moments at which we stand on the verge of the creation of meaning. Those moments are to be savored and appreciated. The skill to be developed is related to the quality of patience, the art of being in those moments.

Education is challenged to create worlds to be experienced, not worlds cut down to the size of our preconceptions. The construction of meaning is the second stage. We jump to it too quickly. We seek the solution before we experience the problem, before we confront the world on its own terms. We need to know the territory, not only the map.

Bob Cover's nomos is a normative world where one does not learn to think a certain way, but where one experiences a complex dialectical tension. It consists of formulated principles, laws and the narratives that inform them, conflict, personal choices, values, struggle, and more. The experience in depth of a nomos is missing from many lives today. It is not a matter of not knowing what to do or what to think. It is a matter of consciousness, of knowing who and where we are.

To learn a nomos is to participate in a normative world, in which formulated law is understood only in its relationships to the rest, to the narratives, to the aspirations, to the hopes. ${ }^{78}$ The process of teaching-teaching anything, law, history, or literature-is immersion in worlds other than our own. The worlds of human history are alien to us, but do we not need to know them if we are to construct our own world of meaning?

78. In fairness to the children, they were probably correct, without knowing why. Because the moon's orbit is not a perfect circle, the spacecraft's route is not a straight line, and the landing point is different from the departure point, it is quite likely that the trips to and from the moon did not traverse the same distance. The children, however, did not necessarily reason in this way. Instead, they relied on their subjective experience - "it seems to me the return trip took longer"-and used it to reach the conclusion that the trips were, objectively, of different lengths.

79. In Nomos and Narrative, supra note 1, at 44 passim, Cover deals extensively with commitment-of judges and of nomic communities-especially as commitment affects the process of judicial inquiry itself. Commitment is not the focus here, but commitment, no less than full participation in a normative world, is magnificently exemplified in Cover's life. 
Law in Education

The study of law, like literature or history, is potentially a rich resource for our lives. But the task of education is to use what scholars say to get back to that world which existed before they said it. The tension between the two produces the educational moment, when what has happened, happens now. Participation in this way in learning the law is empathy, participation in the inquiry itself, for its own sake. As it is in the study of the Talmud. As it was in Bob Cover's life and work. 